\title{
Use of Leg Press 45 to Improve Leg Implusion
}

\author{
Carlos Alberto Kelencz*, Edivane dos Santos Araújo, Bruno Alves da Silva, Jonatha Feliciano Costa, Gustavo \\ Fiais da Rocha and Ligia da Silva Oliveira
}

Centro Universitaro íltalo Brasileiro -Uniítalo - São Paulo - Brazil

Submission: October 10, 2018; Published: March 28, 2019

*Corresponding author: Carlos Alberto Kelencz, Centro Universitaro íltalo Brasileiro -Uniítalo - São Paulo - Brazil

\begin{abstract}
The purpose of this study was to analyse "Leg Press $45^{\circ}$ " and experimentally demonstrate if it is efficient in developing lower limb strength and improving vertical thrust. As an instrument of evaluation, the vertical impulse tests with two variables, horizontal impulse test, maximum load test, body weight and circumference measurements. Tests were applied to twenty students of the Physical Education Course of the University of Santo Amaro, aged between 21 and 30 years. They performed two weekly sessions of the Leg Press 45o exercise every other day during a twomonth period. The results demonstrated that there was increase of force, as well as improvement of the vertical impulse. Therefore, it can be concluded that the Leg Press $45^{\mathrm{o}}$ can be used not only to improve lower limbs strength but also for people who need improvement of vertical impulsion.
\end{abstract}

Keywords: Leg press 45ㅜㅜ Vertical impulsion; Body building

\section{Introduction}

The lower limbs have the largest muscles in our body, and we might also say the most important ones because we need them to carry us through life. With aging, the muscles tend to lose weight and muscle strength. This biological reality can be aggravated by lack of exercise. AS human locomotion is a constant during our existence, the search for exercises that strengthen the lower limbs grew constantly. The ones that offer better results in this sense are: "Squat" and "Leg Press". We know that both have very similar muscular actions, but even so, it cannot be said with certainty which one is the most efficient both to increase the perimeters of the lower limbs and develop strength. For this study we chose to use the Leg Press $45^{\circ}$ as a very good and effective option to strengthen the lower limbs. The present study aims to experimentally demonstrate whether Leg Press $45^{\circ}$ can help increase leg strength and also improve vertical thrust.

\section{Literature Revision}

"Leg Press" as it is known, is one of the bodybuilding exercises that develops the thighs as well as the glutes. This exercise is performed on guided devices, in which the load is placed on a holder that runs on rails. Executed with the column fully supported on the seat, it allows the back to be isolated. This favours its execution by people with back problems, since the load does not affect their backs. There are three types of machines: horizontal leg press, vertical leg press and leg press 45‥The "Leg Press" 45을 which is the most popular and comfortable, is the interest of this research. Its weight support runs on a guide at a $45^{\circ}$ angle to the ground. The seat also has an inclination of $45^{\circ}$, but in the opposite direction to that of the guide. The execution and breathing are the same as the previous ones. It offers more variations for foot positioning because its support platform is bigger than the others.

The name Leg Press stands for "pressure in the legs," and the designation $\left(45^{\circ}\right)$ is linked to the fact that the angle between the ground line and the weight shift of the resultant shaft in the machine forms an exact angle of forty-five degrees $\left(45^{\circ}\right)$ of inclination. The hips and knees extension are needed in the execution of many basic skills such as: jumping, kicking, running, lifting and pulling weights. The combination of hip and knee extension is one of the most important actions in sports activities, specifically in many jumping gestures (high jump, long jump, basketball hooping, jumping to block and cut in volleyball, running and in lifting weights [1] The muscle action in the "Leg Press" is very similar to that of "Squats". The only difference observed is that the erector spines do not participate in the actions because they are totally isolated throughout the movement $[2,3]$.

In a kinesiological analysis, a biarticular movement of knees and hips that extend and flex in the plane and sagittal axis of movement, where the quadriceps is the primary motor muscle, secondarily aided by the gluteus maximus is considered. The antagonistic muscle is the tibialis-ischium [4]. The initial position of the exercise is when knees and hips are flexed, and the final position is when the knees and hips are extended [5]. The efficiency of vertical jumping is imperative for athletes of various sports. Studies show that subjects who performed activities with muscular power (jumps and speed races) were more successful 
in vertical jump, when compared to weight lifters and physically active individuals, consequently, those who presented better performance owed it to a longer phase duration [6-9].

\section{Methodology}

The research was carried out at Campus I of the University of Santo Amaro UNISA, located at Rue ENEA's de Siqueira Net, 340 - Jardim das Imbuias - Santo Amaro, SP Students of the Physical Education course, aged between 21 and 30 years, participated in the experiment, all healthy and practicing bodybuilding. Before starting the experiment, all volunteers were informed of all the research procedures and signed a free and informed consent form. Individuals underwent vertical thrust tests (two variables), with and without the use of arms. These data were recorded in the individual and horizontal control card. In order to determine the load (weight)to be used by each individual, the maximum load test was performed $[10,11]$. They performed their exercises at $70 \%$ of their maximum load [12-15].

\section{Results}

Results Obtained on "Leg Press" After Data Tabulation (Figures 1-6).

\section{Percentage Increase In The Vertical Impulse With} The Aid of The Arms

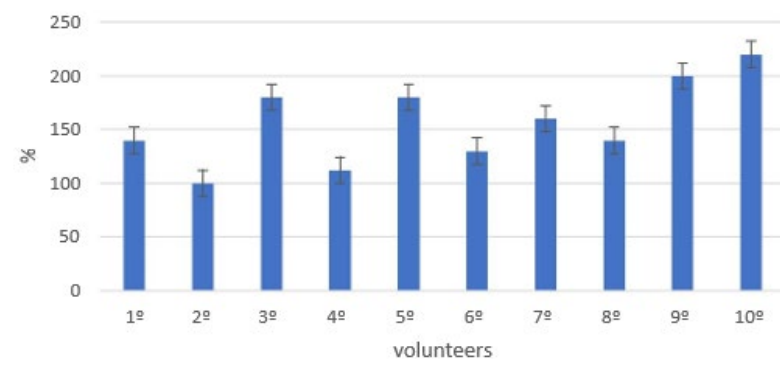

Figure 1: Pre-and post-intervention Gender experience back pain in the control group per age distribution.

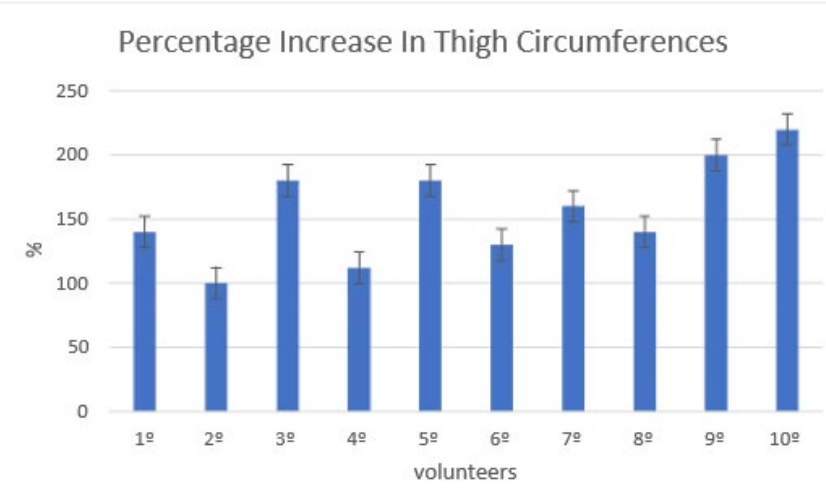

Figure 2: Percentage increase in the circumference of the thighs.

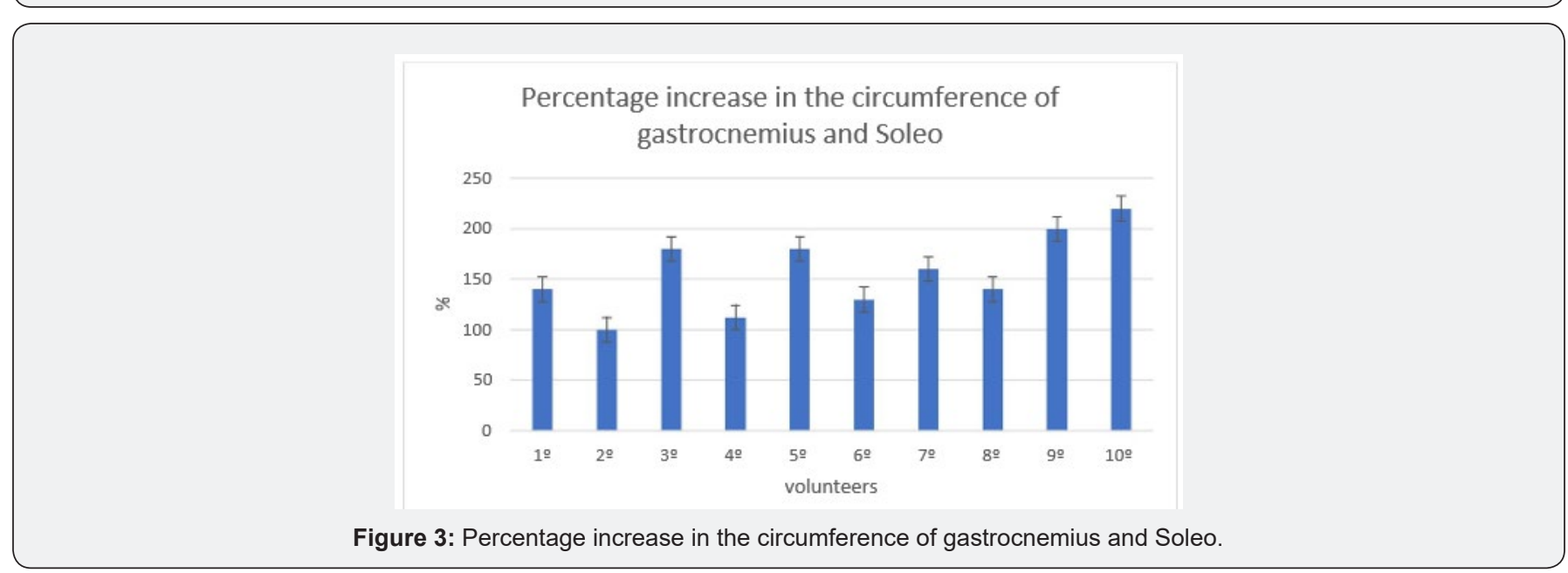



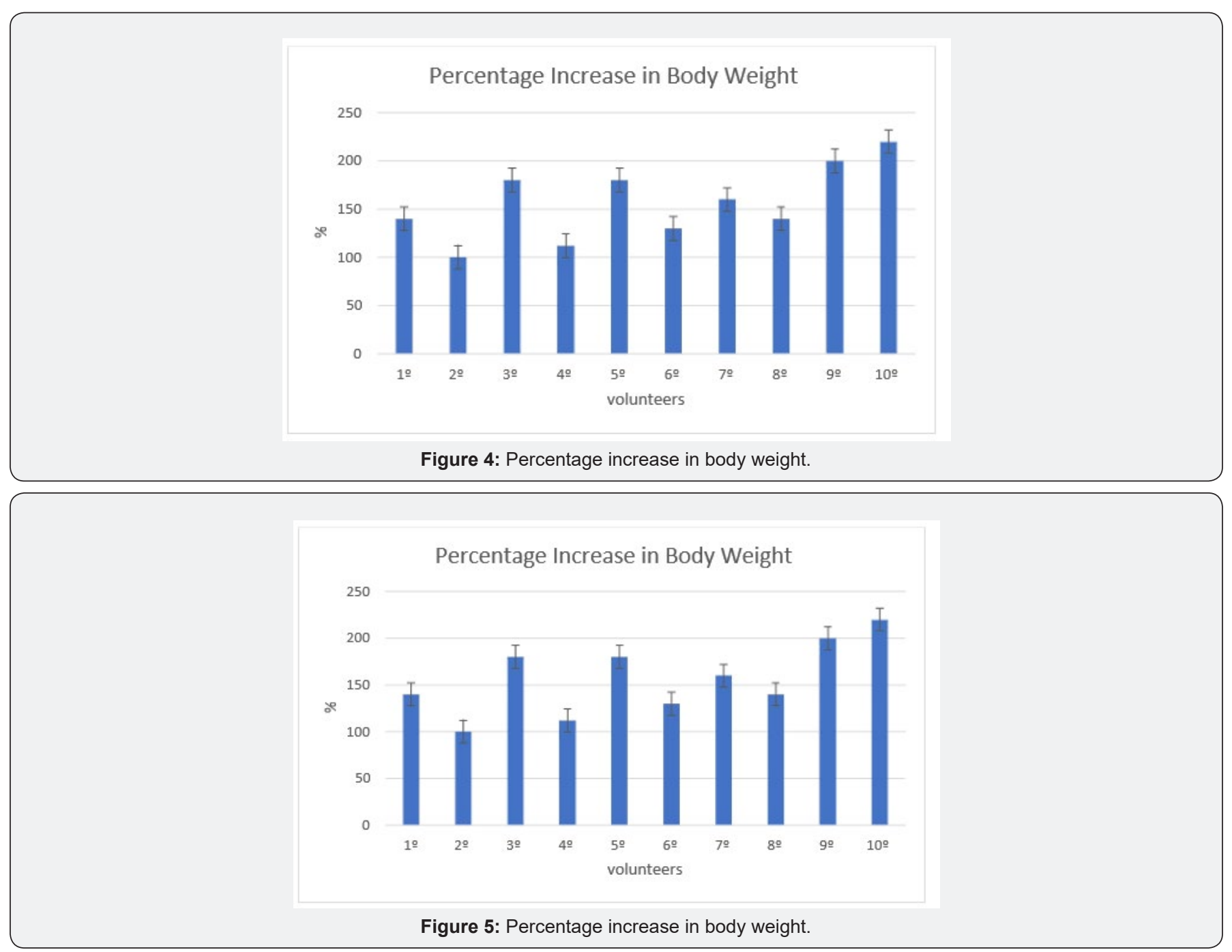

Figure 5: Percentage increase in body weight.

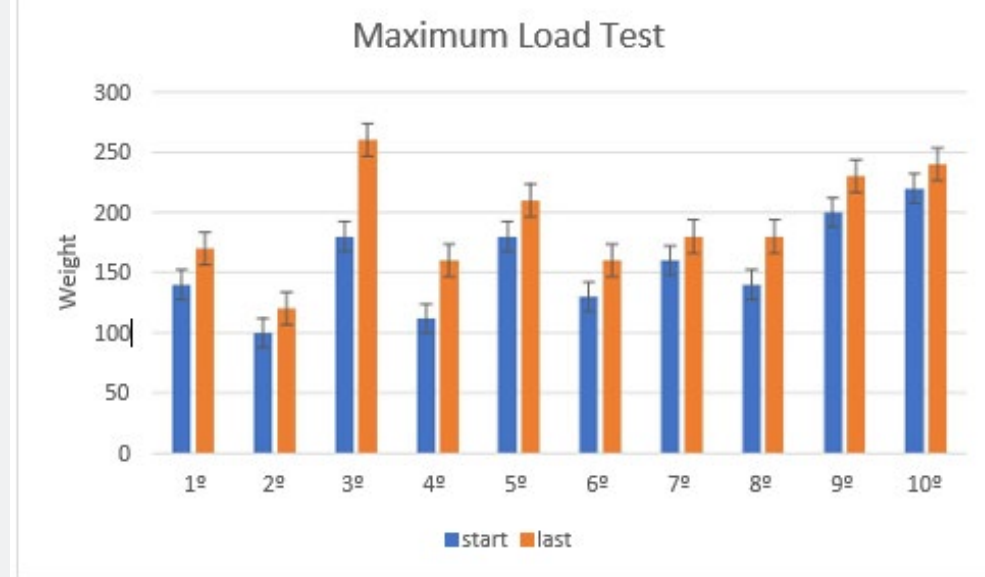

Figure 6: Results of maximum load test.

\section{Discussion}

The average result of the maximum load retest for individuals who used the "Leg Press", had a 23.2\% 6.2\% improvement of strength development in average. The mean result in the vertical push retest, without the aid of the arms, showed a significant improvement in vertical impulsion of $17.7 \% \pm 5 \%$. The average result in vertical jumping retest with the aid of arms, also showed a significant improvement in vertical jumping of $18.6 \pm 3.6 \%$. The result of the retest of the circumference of the calf muscles, showed an almost insignificant improvement, $1.1 \% \pm 0.8 \%$. 
Regarding the body weight of the subjects participating in the research, the following results were observed, $1.1 \% \pm 0.4 \%$. With the results presented, it was possible to observe that the leg press exercise, leads to a better use of concentric contractions preceded by muscle stretching $[16,17]$. A factor to be considered in the improvement of vertical impulsion might be attributed to neural adaptations $[18,19]$.

\section{Conclusion}

Based on the results presented, we concluded that the use of the Leg Press was efficient to improve the strength of the lower limbs as well as to increase their circumference. As for the improvement of vertical impulsion with and without the aid of the arms, a significant increase was observed since this exercise can be safely used by anyone who needs to improve vertical thrust. These results may be of great importance as complementary training in different sports involving vertical thrust.

\section{References}

1. Lombardi G, Vieira N S, Detanico D (2011) Efeito de dois tipos de treinamento de potência no desempenho do salto vertical em atletas de voleibol. Brazilian Journal of Biomotricity 5: 230-238

2. Gentil P, Oliveira E, de Araújo Rocha Júnior V, do Carmo J, Bottaro M. (2007) Effects of exercise order on upper-body muscle activation and exercise performance.J Strength Cond Res 21(4): 1082-1086.

3. Augustsson J, Thomee R, Hornstedt P, Lindblom J, Karlsson J, et_al (2003) Effect of pre-exhaustion exercise on lower-extremity muscle activation during a leg press exercise. J Strength Cond Res 17(2): 411416

4. Enoka, R M (2001) Bases Neuromecânicas da cinesiologia (Neuromechanical Bases of Kinesiology). São Paulo: Manole, Brazil.

5. Hall, S (2000) Biomecânica básica (Basic biomechanics). São Paulo: Guanabara Koogan.

6. Ugrinowitsch C, Tricoli V, Rodacki AL, Batista M, Ricard MD (2007) Influence of training background on jumping height. J Strength Cond Res 21(3): 848-852.

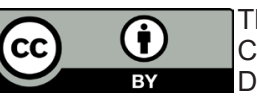

This work is licensed under Creative Commons Attribution 4.0 License DOI: 10.19080/JYP.2019.07.555703
7. Escamilla RF, Zheng N, MacLeod TD, Imamura R, Edwards WB (2010) Cruciate ligament tensile forces during the forward and side lunge. Clinical Biomechanics Bristol 25(3): 213-221.

8. Escamilla RF, Fleisig GS, Zheng N, Lander JE, Barrentine SW, et_al. (2001) Effects of technique variations on knee biomechanics during the squat and leg press. Medicine and Science in Sports Exercise Madison 33(9): 1552-1566.

9. Linthorne NP (2001) Analysis of standing vertical jumps using a force platform. Am J Phys 69(11): 1198-1204.

10. Kraemer WJ, Fry AC (1995) Strength testing: development and evaluation of methodology. Champaign: Human Kinetics.

11. Tan B (1999) Manipulating resistance training program variables to optimize maximum strength in men: a review. J Strength Cond Res 13(3): 289-304.

12. Dias RM, Cyrino R, Salvador ES, Nakamura EP, Pina FY, et_al. (2005) Impacto de oito semanas de treinamento com pesos sobre força muscular de homens e mulheres. Rev Bras Med Esportes 11(4): 224-228.

13. Kraemer WJ, Adams K, Cafarelli E, Dudley GA, Dooly C, et_al. (2002) American college of sports medicine position stand. Progressionmodels in resistance training for healthy adults. Med Sci Sports Exerc 34(2): 364-380.

14. Fleck SJ, Kraemer WJ (2004) Designing resistance training programs. Champaign: Human Kinetics.

15. McDonagh MJ, Davies CT (1984) Adaptive response of mammalian skeletal muscle to exercise with high loads. Eur J Appl Physiol Occup Physiol 52(2): 139-155.

16. Bosco C (2000) La fuerza Muscular. Aspectos metodológicos Barcelona Inde.

17. Häkkinen K, Komi PV (1985) Changes in electrical and mechanical behaviour of leg extensor muscles during heavy resistance strength training. Scandinavian Journal of Sports Sciences 7(2): 55-64.

18. González-Badillo JJ (2000) Tendencias actuales en la investigación de las capacidades condicionales en Alto Rendimiento Deportivo. 1ํ Curso de Doctorado. Universidad Castilla-la Mancha Toledo.

19. Häkkinen K, Komi PV (1985) Effect of explosive type strength training on electromyographic and force production characteristics of leg extensor muscles during concentric and various stretch-shortening cycle exercises. Scand J Sports Sci 7(2): 65-76.

\section{Your next submission with Juniper Publishers} will reach you the below assets

- Quality Editorial service

- Swift Peer Review

- Reprints availability

- E-prints Service

- Manuscript Podcast for convenient understanding

- Global attainment for your research

- Manuscript accessibility in different formats ( Pdf, E-pub, Full Text, Audio)

- Unceasing customer service

Track the below URL for one-step submission https://juniperpublishers.com/online-submission.php 